\title{
Simulation modeling of the long-term evolution of local malaria transmission and acquired immunity in the context of urban growth and urban-rural travel
}

\author{
José G Siri ${ }^{1 *}$, Zachary Brown ${ }^{2}$, Martin Spielauer ${ }^{1,3}$ \\ From Parasite to Prevention: Advances in the understanding of malaria \\ Edinburgh, UK. 20-22 October 2010
}

Malaria occurrence is lower in urban versus rural areas of sub-Saharan Africa for a variety of reasons, including limitation of suitable mosquito habitat, generally improved housing standards and access to prevention and treatment, and a relative decrease in the ratio of vectors to humans. Nonetheless, empirical observation confirms that malaria cases, whether locally transmitted or imported, are frequently observed in cities in endemic areas. Theoretical considerations imply that local transmission will decrease as a city grows, transitioning from a relatively malaria-permissive state to one that encourages reduction or extinction. Using a simple deterministic systems dynamic model based on traditional malaria models, we simulate scenarios for the evolution of local transmission rates and acquired immunity in a homogenous urban area with respect to population size, growth rate, and level of suppression of mosquito breeding. In particular, we consider how the timing and extent of decreases in local transmission are mitigated by travel by city dwellers to endemic rural areas and their resulting exposure to infected mosquitoes. We explore the generalizability and sensitivity to assumptions of our results using microsimulation and analytic methods to account for various aspects of environmental (urban/rural) and demographic heterogeneity. The results of these simulation models should inform projections for long-term urban malaria trends, and have implications for the targeting of malaria prevention efforts in urban and periurban areas of sub-Saharan Africa.

${ }^{1}$ Health and Global Change Project, International Institute for Applied Systems Analysis, Laxenburg, Austria, A-2361

Full list of author information is available at the end of the article
Author details

${ }^{1}$ Health and Global Change Project, International Institute for Applied Systems Analysis, Laxenburg, Austria, A-2361. ${ }^{2}$ Nicholas School of the Environment, Duke University, Durham, NC 27708, USA. ${ }^{3}$ Modeling Division, Statistics Canada, Ottawa, Canada K1A0T6.

Published: 20 October 2010

doi:10.1186/1475-2875-9-S2-P47

Cite this article as: Siri et al: Simulation modeling of the long-term evolution of local malaria transmission and acquired immunity in the context of urban growth and urban-rural travel. Malaria Journal 20109 (Suppl 2):P47.

\section{Submit your next manuscript to BioMed Central and take full advantage of: \\ - Convenient online submission \\ - Thorough peer review \\ - No space constraints or color figure charges \\ - Immediate publication on acceptance \\ - Inclusion in PubMed, CAS, Scopus and Google Scholar \\ - Research which is freely available for redistribution \\ Submit your manuscript at www.biomedcentral.com/submit \\ () Biomed Central}

( 2010 Siri et al; licensee BioMed Central Ltd. This is an open access article distributed under the terms of the Creative Commons 